\title{
Dryland agriculture in India - problems and solutions
}

\section{DOSHNI VIJAYAN}

\author{
Article Chronicle : \\ Received : \\ 16.06.2016; \\ Accepted : \\ 30.11.2016
}

Key Words :

Dryland Agriculture, Economy, Drought, Abiotic stress, Green revolution
ABSTRACT : Dry land agriculture is the agriculture which limits the crop growth to a part of the year due to lack of sufficient moisture (Peterson et al., 2006). 68 per cent of the cultivated area in Indian agriculture comes under dryland, which contributes about 44 per cent of the total food production and plays a critical role in India's food security. A vast majority of the small scale farmers depend on the dry regions for their livelihood. According to the Fourth five year plan of India, dry lands are defined as areas which receive rainfall ranging from $375 \mathrm{~mm}$ to $1125 \mathrm{~mm}$ and with very limited irrigation facilities. Dry regions are economically fragile regions which are highly vulnerable to environmental stress and shocks. Degraded soils with low water holding capacities along with multiple nutrient deficiencies and depleting ground water table contributes to low crop yields and further leading to land degradation. In order to ensure long term sustainability for dry land agriculture in India, various components are to be taken into consideration like socio-economic resources, integrated water shed development, improvement of rain water use efficiency, diversification of agriculture through livestock farming alternative land uses and integrated soil-nutrient-water-crop management. Dry land farming areas needs much closer attention.

HOW TO CITE THIS ARTICLE : Vijayan, Roshni (2016).Dryland agriculture in India - problems and solutions. Asian J. Environ. Sci., 11(2): 171-177, DOI: 10.15740/HAS/AJES/11.2/171-177.

Author for correspondence : 